\title{
ОРГАНІЗАЦЙНІ ЗАСАДИ ДОСЛІДЖЕННЯ ФОРМУВАННЯ СОЦІОКУЛЬТУРНОЇ КОМПЕТЕНТНОСТІ МАЙБУТНІХ ВЧИТЕЛІВ ІНОЗЕМНИХ МОВ НА ЗАСАДАХ МІЖДИСЦИПЛІНАРНОГО ПІДХОДУ
}

Висвітлено логіку розгортання експериментального дослідження формування соиіокультурної компетентності майбутніх вчителів іноземних мов на засадах міждисииплінарного підходу. Дослідження формування соиіокультурної компетентності майбутніх вчителів іноземних мов на засадах міждисциплінарного підходу базується на організаиії та проведенні педагогічного експерименту.

Згідно з поставленими иілями логіка проведення дослідно-експериментальної роботи уможливила обгрунтування ї̈ етапів, які характеризувалися чітко окресленими завданнями, відповідними формами і методами організації. Під час першого (пошуково-теоретичного) етапу (2017 рік) було здійснено поглиблений аналіз наукових літературних джерел філософського, психолого-педагогічного, науково-методичного, історико-педагогічного спрямування, опрацьовано періодичні науково-методичні видання та матеріали науково-практичних зібрань (конферениій, симпозіумів, семінарів) з метою узагальнення теоретичних засад формування соціокультурної компетентності майбутніх вчителів іноземних мов на засадах міждисциплінарного підходу.

Під час другого (діагностично-констатувального) етапу (2017-2018 н.р.) було визначено мету, завдання, провідну ідею дисертаційної роботи; вивчено та адаптовано існуючий діагностичний інструментарій і розроблено авторські тести для встановлення стану сформованості соиіокультурної компетентності майбутніх вчителів іноземних мов на засадах міждисциплінарного підходу; висунуто та конкретизовано гіпотезу й концептуальні засади формування соиіокультурної компетентності майбутніх вчителів іноземних мов на засадах міждисииплінарного підходу.

Авторська методика формування соціокультурної компетентності майбутніх вчителів іноземних мов на засадах міждисииплінарного підходу вбудована у логіку організації третього (формувального) етапу експериментального дослідження, який тривав протягом 2018-2019 н.р. Перевірка аналізу результатів експериментального дослідження формування соиіокультурної компетентності майбутніх вчителів іноземних мов на засадах міждисциплінарного підходу передає зміст підсумкового етапу експериментального дослідження (2020 рік).

Ключові слова: компетентність, сочіокультурна компетентність, компонент, етап, організація, майбутні вчителі іноземних мов.

\author{
Kateryna FODOR, \\ orcid.org/0000-0002-5086-0944 \\ Postgraduate Student at the Department of Pedagogy \\ Mukachevo State University
} (Mukachevo, Transcarpathian region, Ukraine)fodor.katalin@kmf.org.ua

\section{ORGANIZATIONAL FUNDAMENTALS OF THE RESEARCH ON FORMING SOCIOCULTURAL COMPETENCE OF FUTURE TEACHERS OF FOREIGN LANGUAGES ON THE BASIS OF INTERDISCIPLINARY APPROACH}

In the article the logic of the development of experimental research on forming sociocultural competence of future teachers of foreign languages on the basis of interdisciplinary approach is highlighted. The research on forming sociocultural competence of future foreign language teachers on the basis of interdisciplinary approach is based on organization and conducting a pedagogical experiment.

According to the set goals, the logic of conducting experimental work made it possible to substantiate its stages, which were characterized by clearly defined tasks and appropriate forms and methods of organization. During the first stage, i.e. the exploratory-theoretical one, which was completed in 2017 an in-depth analysis of literary sources of philosophical, psychological-pedagogical, scientific-methodical and historical-pedagogical factors was carried out, publications of scientific-methodical journals and materials of scientific-practical conferences were analized in order to generalize the

\footnotetext{
${ }^{1}$ Статтю написано за сприяння програми Колегіум Талентум (Угорщина, 2020 рік).
} 
theoretical foundations of forming sociocultural competence of future teachers of foreign languages on the basis of interdisciplinary approach.

The second stage, i.e. the diagnostic and ascertaining one, which was completed in 2017-2018 academic year - is reflected in the purpose, tasks and the leading idea of the dissertation. During this stage the existing diagnostic tools were studied and the author's tests were designed to establish the state of forming sociocultural competence of future foreign language teachers on the basis of interdisciplinary approach; moreover, the hypothesis was formulated, and the conceptual foundations of forming sociocultural competence of future teachers of foreign languages on the basis of the interdisciplinary approach were concretized.

The method of forming sociocultural competence of future foreign language teachers on the basis of interdisciplinary approach is built into the logic of the organization of the third, formative stage of the experimental research, which lasted during 2018-2019 academic year. Analysis of the results of the experimental study of forming sociocultural competence of future foreign language teachers on the basis of an interdisciplinary approach reflects the content of the final stage of the experimental study (2020).

Key words: competence, sociocultural competence, component, stage, organization, future foreign language teachers.

Постановка проблеми. Дослідження формування соціокультурної компетентності майбутніх вчителів іноземних мов на засадах міждисциплінарного підходу передбачало організацію та проведення педагогічного експерименту. 3 метою пояснення його специфіки та логіки здійснення вважаємо за доцільне здійснити детальний аналіз категорій «експеримент», «педагогічний експеримент».

Сучасне розуміння поняття «експеримент» свідчить про багато різних трактувань. Наведемо огляд деяких із них, спрямований на побудову власної версії, що має ознаки використовуваних авторами визначень і дає змогу відповісти на поставлені питання й організувати діяльність дослідника в режимі експерименту. У «Короткій філософській енциклопедії» експеримент визначається як «планомірно проведене спостереження; планомірна ізоляція, комбінація і варіювання умов 3 метою вивчення залежних від них явищ» (Краткая философская энциклопедия, 1994: 156). Так науковець створює можливість спостережень, на основі яких складається нове знання про закономірності функціонування досліджуваного явища.

Слушною вважаємо думку В. Загвязинського, який, визначаючи сутність дидактичного дослідження, за основу бере тлумачення, в якому експериментом $€$ зміна або відтворення явища 3 метою вивчення його в найбільш сприятливих умовах (Загвязинский, 1981: 160). Характерною рисою експерименту є заплановане втручання в досліджуваний процес, можливість багаторазового відтворення досліджуваних явищ у змінних умовах.

Метод експерименту, за словами В. Загвязинського (Загвязинский, 1981: 128), дозволяє розкласти цілісні педагогічні явища на складники. Змінюючи умови, в яких такі елементи функціонують, експериментатор отримує можливість простежувати розвиток окремих сторін і зв'язків, більш-менш точно фіксувати отримані результати. Тому експеримент вживається для перевірки гіпотези, уточнення окремих висновків теорії (емпірично перевірених наслідків), встановлення та уточнення фактів.

Найбільш істотними ознаками експерименту $\epsilon$ відтворюваність, перевірка гіпотези, встановлення й уточнення фактів. М. Поташник, розглядаючи застосування поняття «експеримент» у педагогічній практиці, виокремлює множинність використовуваних тлумачень. Проте всі вони «еквівалентні, з будь-якого можна вивести всі інші, кожне 3 них сильніше висвітлює ту чи іншу сторону цього явища» (Поташник, 1991: 8). Нині в наукових колах у загальному розумінні під експериментом розуміється загальнонауковий метод пізнання, за допомогою якого в контрольованих і керованих умовах досліджуються явища дійсності.

Аналіз досліджень. Проблеми визначення ключових умов ефективності методики дослідноекспериментальної роботи, пов'язаних із проведенням педагогічного експерименту, були предметом наукових розвідок низки науковців (Батаршев, 2007; Кивирялг, 1980; Лузан, 2011; Штульман, 1988). Питання формування соціокультурної компетентності майбутніх фахівців знайшли відображення у наукових доробках Н. Білоцерківської (2009), І. Закір'янової (2002), В. Калініна (2003), В. Киливника (2018).

Мета статті - висвітлити логіку розгортання експериментального дослідження формування соціокультурної компетентності майбутніх вчителів іноземних мов на засадах міждисциплінарного підходу.

Виклад основного матеріалу. Підкреслюючи багатофункціональність педагогічного експерименту, трактуємо його як науково обгрунтований досвід організації освітньої діяльності з метою пошуку нових, ефективніших способів вирішення педагогічних проблем; як дослідницьку діяльність щодо вивчення причинно-наслідкових зв'язків у педагогічному явищі й умов його протікання. В межах дослідження педагогічний екс- 
перимент розглядаємо як комплекс пізнавальних операцій, пов'язаних із вивченням педагогічних чинників, явищ, процесів у спеціально створених умовах для з'ясування властивостей, зв'язків, закономірностей.

Для педагогічного експерименту характерними є такі особливості:

- зумисне внесення у педагогічний процес принципово важливих змін згідно із завданнями та гіпотезою дослідження;

- організація педагогічного процесу, яка дає змогу встановлювати зв'язки між явищами без порушення його цілісного характеру;

- глибокий якісний аналіз і точний кількісний вимір внесених у педагогічний процес нових та/ або видозмінених компонентів і результатів експерименту загалом.

Авторська експериментальна методика формування соціокультурної компетентності майбутніх вчителів іноземних мов на засадах міждисциплінарного підходу пройшла процедуру апробації 3 метою іiі подальшої адаптації та впровадження в освітній процес вищої школи. Мета дослідноекспериментальної роботи полягала в дослідженні результативностіпедагогічних умов таструктурнофункціональної моделі формування соціокультурної компетентності майбутніх вчителів іноземних мов на засадах міждисциплінарного підходу.

Різноманітність існуючих у педагогіці дослідних програм, реальних контекстів дослідження (теоретичних і практичних завдань), можливостей, якими володіє дослідник, а також технічних та етичних обмежень, які виникають у науководослідницькій практиці, $є$ причиною того, що конкретні методики дослідження істотно відрізняються. Такі конкретні стратегії організації наукових розвідок розглядаються як методи науковопедагогічного дослідження, застосування яких спрямовувалося на отримання висновків методологічного, теоретичного та практичного характеру.

Вибір конкретних методів дослідження визначався характером фактичного матеріалу, умовами і метою такого дослідження. Методи добиралися відповідно до завдань конкретного етапу дослідження. Прийоми та операції 3 теоретичним i фактичним матеріалом було реалізовано в послідовності, заданій програмою дослідження. Так, на теоретичному етапі дослідження використовувалися методи збору інформації, вивчення джерел, системний аналіз, сходження від абстрактного до конкретного. На етапі збору фактичного матеріалу були застосовані методи емпіричного дослідження: експеримент, спостереження, опитування, оброблення й аналіз отриманих даних (кількісний і якісний аналіз), їх систематизація та узагальнення. У процесі узагальнення даних експериментального пошуку використовувалися візуальні (графічні) методи (схеми, діаграми, графіки). На етапі аналізу результатів дослідження мали місце верифікаційні методи, які дали змогу перевірити одержані результати, визначити рівень їх значущості, довести істинність гіпотези та сформулювати висновки.

Педагогічний експеримент передбачає навмисне теоретично обгрунтоване внесення змін в організацію педагогічного процесу, що здійснюється 3 метою оцінки і (або) порівняння ефективності педагогічних нововведень, а також вивчення характеру зв'язків між різними компонентами освіти і педагогічними явищами, між факторами, умовами i результатами педагогічного впливу. Ключовим етапом педагогічного експерименту $\epsilon$ його планування, адже будь-який педагогічний експеримент має структуру й логіку проведення, що пов'язано 3 дослідницькими операціями та їхньою класифікацією. Згідно 3 поставленими цілями логіка проведення дослідно-експериментальної роботи уможливила визначення та обгрунтування iï етапів, які характеризувалися чітко окресленими завданнями, відповідними формами і методами організації: пошуково-теоретичний - 2017 р.; діагностично-констатувальний 2017-2018 н.р.; формувальний - 2018-2019 н.р.; аналітично-підсумковий - 2020 р.

Розглянемо детальніше зміст кожного етапу. Так, протягомпершого етапуздійснено поглиблений аналіз наукових літературних джерел філософського, психолого-педагогічного, науково-методичного, історико-педагогічного спрямування, опрацьовано періодичні науково-методичні видання та матеріали науково-практичних зібрань (конференцій, симпозіумів, семінарів) 3 метою узагальнення теоретичних засад формування соціокультурної компетентності майбутніх вчителів іноземних мов на засадах міждисциплінарного підходу. Аналіз наукової літератури з досліджуваної проблеми відбувався постійно до завершення роботи над дисертацією з метою уточнення сутності основних понять дисертаційного дослідження в контексті сучасної педагогічної науки й доведення правильності вибраних методів шляхом порівняння 3 результатами педагогічних пошуків інших дослідників.

Пошуково-теоретичний етап наукової розвідки характеризувався такими процесами:

- виявлено актуальність проблеми формування соціокультурної компетентності майбутніх вчителів іноземних мов на засадах міждисциплінарного підходу; 
- виокремлено соціально-культурні передумови модернізації професійної підготовки майбутніх вчителів іноземних мов;

- на основі вивчення літературних джерел, нормативно-правової документації та інших матеріалів, аналізу практичного досвіду підготовки майбутніх вчителів іноземних мов виявлено низку суперечностей, які стають на заваді розв'язанню актуальних проблем формування у студентів соціокультурної компетентності на засадах міждисциплінарного підходу.

Діагностично-констатувальний етап передбачав роботу зі студентами, які на момент вступу в експеримент закінчували IV курс навчання. Вказаний етап наукової розвідки передбачав такі дії:

- визначено мету, завдання, провідну ідею дисертаційної роботи;

- вивчено та адаптовано існуючий діагностичний інструментарій та розроблено авторські тести для встановлення стану сформованості соціокультурної компетентності майбутніх вчителів іноземних мов на засадах міждисциплінарного підходу;

- висунуто, конкретизовано гіпотезу й концептуальні засади формування соціокультурної компетентності майбутніх вчителів іноземних мов на засадах міждисциплінарного підходу;

- конкретизовано структурні складники соціокультурної компетентності майбутніх вчителів іноземних мов;

- конкретизовано рівні сформованості цього феномену у студентів та узагальнено сукупність показників для кожного рівня;

- визначено, теоретично обгрунтовано педагогічні умови і розроблено структурно-функціональну модель формування соціокультурної компетентності майбутніх вчителів іноземних мов на засадах міждисциплінарного підходу;

- проведено констатувальну частину експерименту, в результаті чого встановлено необхідність цілеспрямованого формування соціокультурної компетентності майбутніх вчителів іноземних мов на засадах міждисциплінарного підходу.

Авторська методика формування соціокультурної компетентності майбутніх вчителів іноземних мов на засадах міждисциплінарного підходу вбудована в логіку організації третього (формувального) етапу експериментального дослідження, який тривав протягом 2018-2019 н.р. і дав змогу досягнути таких результатів:

- спроектувати соціокультурне середовище формування соціокультурної компетентності майбутніх вчителів іноземних мов на засадах міждисциплінарного підходу;
- конкретизуватизасоби формування соціокультурної компетентності майбутніх вчителів іноземних мов на засадах міждисциплінарного підходу;

- розробити й апробувати експериментальну методику реалізації педагогічних умов та структурно-функціональної моделі формування соціокультурної компетентності майбутніх вчителів іноземних мов на засадах міждисциплінарного підходу;

- провести формувальний етап дисертаційного дослідження, у процесі якого здійснено експериментальну перевірку гіпотези ефективності педагогічних умов і структурно-функціональної моделі;

- здійснити апробацію авторської методики для цілеспрямованого формування досліджуваної компетентності;

- на основі використання методів спостереження, бесіди, опитування, анкетування, аналізу дієвості різних структурних компонентів розробленої методики визначити проблемні місця запропонованої структурно-функціональної моделі; внести корективи в педагогічне забезпечення іï функціонування.

Перевірка аналізу результатів експериментального дослідження формування соціокультурної компетентності майбутніх вчителів іноземних мов на засадах міждисциплінарного підходу передає зміст підсумкового етапу експериментального дослідження (2020р.), під час якого було:

- узагальнено результати формувального етапу експериментального дослідження;

- внесено доповнення та уточнення у зміст основних теоретичних положень;

- систематизовано дослідницькі матеріали та викладено результати дослідження в тексті дисертації та навчально-методичних розробках для формування соціокультурної компетентності майбутніх вчителів іноземних мов на засадах міждисциплінарного підходу;

- здійснено експериментальну перевірку ефективності впровадження педагогічних умов та структурно-функціональної моделі;

- впроваджено основні результати дослідження в педагогічну практику закладів вищої освіти, в яких здійснюється професійна підготовка майбутніх вчителів іноземних мов;

- оброблено та проаналізовано отримані дані, здійснено порівняльний аналіз ефективності традиційної підготовки студентів, які здобувають освітньо-кваліфікаційний рівень бакалавра галузі знань 01 «Освіта» за напрямом 014 Середня освіта (Англійська мова та зарубіжна література) для реалізації запропонованої в дослідженні інноваційної методики формування соціокультурної 
компетентності майбутніх вчителів іноземних мов на засадах міждисциплінарного підходу;

- систематизовано й узагальнено результати експериментального дослідження; доведено їx вірогідність шляхом використання методів математичної статистики;

- сформульовано висновки; здійснено прогностичне обгрунтування розробленої експериментальної системи; визначено перспективи подальших розвідок.

Висновки. Отже, експериментальне дослідження формування соціокультурної компетентності майбутніх вчителів іноземних мов на засадах міждисциплінарного підходу здійснювалося протягом 2017-2020 років й охоплювало чотири етапи: пошуково-теоретичний, діагностично-констатувальний, формувальний та аналітично-підсумковий. Ці етапи педагогічного експерименту є чітко алгоритмізованими і послідовними, що забезпечує структурну доцільність експериментальної діяльності щодо формування досліджуваної компетентності у студентів, які здобувають освітньо-кваліфікаційний рівень бакалавра галузі знань 01 «Освіта» за напрямом 014 Середня освіта (Англійська мова та зарубіжна література).

Перспективи подальших розвідок у цьому напрямі вбачаємо в окресленні особливостей реалізації методики формування соціокультурної компетентності майбутніх вчителів іноземних мов на засадах міждисциплінарного підходу.

\section{СПИСОК ВИКОРИСТАНИХ ДЖЕРЕЛ}

1. Білоцерківська Н. Г. Формування соціокультурної компетентності майбутніх вчителів у процесі вивчення гуманітарних дисциплін : автореф. дис. канд. пед. наук: 13.00.04. Харків, 2009. 20 с.

2. Батаршев А. В., Алексеева И. Ю., Майорова Е. В. Диагностика профессионально-важных качеств. СПб : Питер, 2007. $192 \mathrm{c}$.

3. Загвязинский В. И. Методология и методика дидактического исследования. М. : Педагогика, 1981. 160 с.

4. Закір'янова I. А. Динаміка соціокультурної компетентності майбутніх педагогів. Теоретичні питання культури, освіти та виховання : зб. наук. $n р$. К. : Вид. центр КДЛУ, 2002. Вип. 21. С. 183-Калінін В. О. Особливості формування соціокультурної компетенції майбутнього вчителя іноземної мови у процесі професійно-педагогічної підготовки. Вісник Житомир. пед. ун-ту. 2003. № 12. С. 154-156.

5. Краткая философская энциклопедия. М. : Энциклопедия, 1994. 576 с.

6. Кыверялг А. А. Методы исследования в профессиональной педагогике. Таллин : «Валгус», 1980. 334 с.

7. Киливник В. Педагогічні умови формування соціокультурної компетентності майбутніх вчителів іноземної мови. Педагогічні науки: теорія, історія, інноваиійні технології. 2018. № 2 (76). С. 156-166.

8. Лузан П. Г., Сопівник І. В., Виговська С. В. Основи науково-педагогічних досліджень. К. : НАКККіМ, 2011. 314 с.

9. Поташник М. М. Эксперимент в школе: организация и управление. М. : МГПУ, 1991. 215 с.

10. Штульман Э. А. Специфика методического эксперимента. Сов. педагогика. 1988. № 3. С. 61-65.

\section{REFERENCES}

1. Bilotserkivska N. H. (2009) Formuvannia sotsiokulturnoi kompetentnosti maibutnikhu chyteliv u protsesi vyvchennia humanitarnykh dystsyplin [Formation ofsociocultural competence of future teachers in the process of studying the humanities] : avtoref. dys. kand. ped. nauk: 13.00.04. Kharkiv. 20 s. [in Ukrainian]

2. Batarshev A. V., Alekseeva Y. Yu., Maiorova E. V. (2007). Dyahnostyka professyonalnovazhnikh kachestv [Diagnosis of professionally important qualities]. SPb : Pyter, 192 s. [in Russian].

3. Zahviazynskyi V. Y. (1981). Metodolohyia y metodyka dydaktycheskoho yssledovanyia [Methodology and methods of didactic research]. M. : Pedahohyka. 160 s. [in Russian].

4. Zakirianova I. A. (2002). Dynamika sotsiokulturnoi kompetentnosti maibutnikh pedahohiv [Dynamics of sociocultural competence of future teachers]. Teoretychni pytannia kultury, osvity ta vykhovannia [Theoretical issues of culture, education and upbringing] : zb. nauk. pr. K. : Vyd. tsentr KDLU. Vyp. 21. S. 183-189 [in Ukrainian]

5. Kalinin V. O. (2003). Osoblyvosti formuvannia sotsiokulturnoi kompetentsii maibutnoho vchytelia inozemnoi movy $\mathrm{u}$ protsesi profesiino-pedahohichnoi pidhotovky [Features of the formation of sociocultural competence of the future teacher of a foreign language in the process of professional and pedagogical training]. Visnyk Zhytomyr. ped. un-tu. № 12. S. 154-156 [in Ukrainian].

6. Kratkaia fylosofskaia entsyklopedyia[A briefphilosophicalencyclopedia](1994). M.: Эntsyklopedyia.576s. [in Russian].

7. Kuverialh A. A. (1980). Metodu yssledovanyia v professyonalnoi pedahohyke [Research methods in professional pedagogy]. Tallyn : "Valhus". 334 s. [in Russian].

8. Kylyvnyk V. (2018). Pedahohichni umovy formuvannia sotsiokulturnoi kompetentnosti maibutnikh uchyteliv inozemnoi movy [Pedagogical conditions of the formation of sociocultural competence of future foreign language teachers]. Pedahohichni nauky: teoriia, istoriia, innovatsiini tekhnolohii. № 2 (76). S. 156-166 [in Ukrainian].

9. Luzan P. H., Sopivnyk I. V., Vyhovska S. V. (2011). Osnovy naukovo-pedahohichnykh doslidzhen [Fundamentals of scientific and pedagogical research]. K. : NAKKKiM. 314 s. [in Ukrainian].

10. Potashnyk M. M. (1991). Eksperyment v shkole: orhanyzatsyia y upravlenye [Experiment in school: organization and management]. M. : MHPU. 215 s. [in Russian].

11. Shtulman E. A. (1988). Spetsyfyka metodycheskoho eksperymenta [Specifics of the methodical experiment]. Sov. pedahohyka. № 3. S. 61-65 [in Russian]. 